\title{
МОНТТОРИНГ
}

\section{ЯК ВАЖЛИВА СКЛАДОВА ПОКРАЩЕННЯ ЯКОСТІ ОСВІТИ}

\author{
М. С. Осійчук ${ }^{1}$, О. П. Волосовець ${ }^{1}$ Ю. С. П'ятницький ${ }^{1}$, К. В. Баранніков ${ }^{1}$,
} Л. В. Соколова² ${ }^{2}$ І. В. Мельник², Т. І. Фаріон ${ }^{2}$ М. О. Поліщук²

${ }^{\prime}$ Міністерство охорони здоров'я Украӥни,

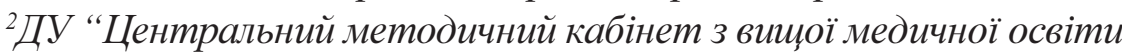
МOЗ України”

\section{MONITORING AS AN IMPORTANT COMPONENT OF IMPROVING THE QUALITY OF EDUCATION}

\author{
M. S. Osiychuk ${ }^{1}$, O. P. Volosovets ${ }^{1}$, Yu. S. Pyatnytsky ${ }^{1}$, K. V. Barannikov ${ }^{1}$, \\ L.V. Sokolova², I. V. Melnyk ${ }^{2}$, T. I. Farion ${ }^{2}$, M. O. Polishchuk ${ }^{2}$ \\ ${ }^{I}$ Ministry of Public Health of Ukraine, \\ ${ }^{2}$ SI "Central Methodical Cabinet of Higher Medical Education of MPH of Ukraine"
}

\begin{abstract}
У статті висвітлено моніторинг навчально-методичної діяльності ВНЗ МОЗ України як важливу складову покращення надання освітніх послуг.
\end{abstract}

The article deals with monitoring educational and methodical activity of HEI of MPH of Ukraine as an important part of improving the delivery of educational services.

Вступ. Покращення якості надання освітніх послуг і фахової підготовки лікарів та фармацевтів залишається пріоритетним завданням вищих медичних (фармацевтичного) навчальних закладів IV рівня акредитації МОЗ України (далі - ВМ(Ф)НЗ) [2].

Якість освіти у всьому світі визначається не тільки обсягом знань, але й параметрами особистісного, світоглядного, громадянського розвитку, при цьому проблема якості освітнього процесу розглядається 3 позицій загальнолюдської і соціальної цінності освіти. Саме ці чинники актуалізують проблему управління якістю освіти у вищому навчальному закладі. Моніторинг є складовою управління якістю освіти [3].

У розділі VII "Національний моніторинг та оцінка системи освіти" Національної стратегії розвитку освіти в Україні на період до 2021 року, схваленої Указом Президента України № 344/2013 від 25 червня 2013 року, зазначено: "Ефективність реалізації управління у сфері освіти значною мірою залежить від того, наскільки система моніторингу та оцінки якості осві-

() М. С. Осійчук, О. П. Волосовець, Ю. С. П'ятницький та ін. ти відповідає цілям і завданням державної політики у цій сфері та наскільки управлінські рішення, що приймаються, адекватні результатам і рекомендаціям моніторингових досліджень".

Міністерство охорони здоров'я України наказом № 834 від 24 жовтня 2012 року "Про навчальнометодичну діяльність вищих медичних та фармацевтичних навчальних закладів I - IV рівнів акредитації” запровадило проведення постійного системного моніторингу навчально-методичної діяльності вищих медичних та фармацевтичних навчальних закладів I - IV рівнів акредитації (далі - вищі навчальні заклади) та закладів післядипломної освіти, зокрема організацію роботи моніторингових робочих груп у вищих навчальних закладах, у яких здійснюється підготовка спеціалістів для сфери охорони здоров'я.

Метою моніторингу є вивчення якості підготовки медиків і фармацевтів, стану та особливостей навчально-методичної діяльності навчальних закладів з урахуванням наявних ліцензованих спеціальностей, обсягів, напрямів та специфіки підготовки. 
Основна частина. За результатами моніторингу, проведеного у вищих навчальних закладах МО3 України протягом 2012 - 2014 років, підготовлені довідки, в яких зазначались виявлені недоліки, пропозиції щодо покращення організації навчально-методичної роботи і якості підготовки спеціалістів, відзначався позитивний досвід роботи для впровадження у діяльність інших навчальних закладів.

Моніторинг здійснюється 3 урахуванням вимог Постанови Кабінету Міністрів України № 1283 від 14 грудня 2011 року “Про затвердження Порядку проведення моніторингу та оцінки якості освіти” із змінами, внесеними згідно з Постановою Кабінету Міністрів України № 342 від 29 квітня 2013 року, зокрема шляхом:

- опитування різних груп;

- збору статистичних даних (встановленої форми);

- вивчення документів навчальних закладів.

Доцільно зазначити, що основними завданнями моніторингу та оцінки, відповідно до зазначеної постанови Кабінету Міністрів України, є:

- отримання об'єктивної інформації про якість освіти, стан системи освіти, а також прогнозування їі розвитку;

- оцінювання стану системи освіти відповідно до завдань державної політики у галузі освіти;

- забезпечення органів державної влади статистичною та аналітичною інформацією про якість освіти.

Основними ж методами проведення моніторингу та оцінки визначено:

- об'єктивність оброблення інформації про якість освіти;

- системність оцінювання якості освіти;

- оперативність доведення до відома органів управління освітою та громадськості підсумків моніторингу.

Під час проведення моніторингу навчальнометодичної діяльності вищих навчальних закладів та закладів післядипломної освіти MO3 України ураховували питання, передбачені у Програмі дотримання вищими навчальними закладами Ліцензійних умов надання освітніх послуг, затвердженій наказом Державної інспекції навчальних закладів України № 28-а від 4 липня 2012 року (далі - Програма). Зокрема, у таблиці 2 додатка 5 Програми зазначені управлінські заходи щодо забезпечення якості підготовки студентів: наявність у вищому навчальному закладі центру (відділу) моніторингу якості підготовки та відповідного положення; наявність штатних працівників або недостатній рівень їхньої підготовки; результати ректорського контролю є вищими за семестровий; періодичність роз- гляду питання щодо якості підготовки в межах контролю на рівні вчених рад вищих навчальних закладів, деканатів (вчених рад факультетів), кафедр; участь у контролюванні якості підготовки органів студентського самоврядування [5, 6].

Необхідно нагадати, що у рішенні колегії Міністерства освіти і науки України (протокол № 4/1-4 від 2 квітня 2009 року "Мета реформ у вищій школі якість і доступність освіти" було наголошено на необхідності вжиття заходів щодо подальшого удосконалення системи внутрішнього моніторингу якості вищої освіти, запровадження в усіх вищих навчальних закладах моніторингу якості освітніх послуг з урахуванням оцінок студентства.

Міністерство охорони здоров' я України відповідно до пункту 6.12 Положення про Міністерство охорони здоров’ я України, затвердженого Указом Президента України № 467 від 13 квітня 2011 року, з метою визначення вимог до професійної підготовки та підвищення кваліфікації медичних, фармацевтичних працівників сфери охорони здоров'я і для поліпшення якості організації навчального процесу доручило запровадити у структурі навчального закладу сектор (відділ) моніторингу якості освіти (лист № 08.01-47/1441 від 4 серпня 2009 року до ректорів ВМ(Ф)НЗ). Згідно 3 листом МОЗ України № 08.01-47/1602 від 4 серпня 2010 року усі ВМ(Ф)НЗ проінформували МОЗ України про запровадження у своїх структурах таких секторів (відділів) моніторингу якості освіти.

Разом з тим необхідно наголосити, що у сучасній українській педагогічній науці недостатньо розроблені підходи до виявлення критеріїв якості вищої освіти, механізми моніторингу та процеси його застосування, відсутні компактні аналітико-діагностичні технології здійснення зворотного зв' язку. Постійно діючий моніторинг ще не став важливою складовою системи професійної підготовки майбутніх фахівців $[3,5,6]$.

Моніторинг можна визначити як “постійне спостереження за будь-яким процесом з метою виявлення його відповідності бажаному результату або вихідним пропозиціям". Він передує плануванню й прийняттю рішень; спрямований на основні параметри навчального процесу; має статус дослідження, а не емпіричного збору матеріалу; має комплексний, системний характер; створює умови для планування - річного, перспективного, стратегічного. При цьому моніторинг в освіті поєднує три важливі управлінські компоненти:

- аналіз, оцінку й прогнозування процесів в освіті;

- сукупність прийомів відстеження процесів в освіті; 
- збір і обробку інформації з метою підготовки рекомендацій щодо розвитку досліджуваних процесів і внесення необхідних коректив.

Необхідно наголосити, що моніторинг грунтується на цих компонентах, але не заміняе жодного з них, оскільки не може бути ні контролем, ні експертизою, ні системою інформаційного забезпечення. Без функціонування у навчальному закладі усіх цих напрямів діяльності організація моніторингу неможлива.

На сьогодні основними завданнями моніторингу якості освіти у вищих навчальних закладах є:

1) розробка комплексу показників, що забезпечують цілісне уявлення про стан освітнього процесу, про якісні й кількісні зміни у ньому;

2) систематизація інформації про стан і розвиток освітнього процесу у вищому навчальному закладі;

3) забезпечення постійного й наочного представлення інформації про процеси, що відбуваються у вищому навчальному закладі;

4) інформаційне забезпечення аналізу й прогнозування стану й розвитку освітнього процесу, вироблення управлінських рішень.

Одним із важливих завдань моніторингу є попередження проте чи іншенеблагополуччя, анепросто констатація факту появи змін, що представляють небезпеку, з метою створення можливості запобігти або мінімізувати ймовірний деструктивний розвиток подій [3].

MO3 України з урахуванням підсумків моніторингу, проведеного у більшості ВМ(Ф)НЗ на виконання наказу МОЗ України № 834 від 24 жовтня 2012 року, рекомендовано враховувати під час організації навчально-методичної роботи досвід, набутий фахівцями таких навчальних закладів:

- Харківського національного медичного університету, ДВНЗ “Національний фармацевтичний університет”, Донецького національного медичного університету імені М. Горького-щодо організації підготовки науково-педагогічних кадрів, формування резерву на посади завідувачів кафедр;

- Запорізького державного медичного університету, ДВНЗ “Національний фармацевтичний університет”, ДЗ “Луганський державний медичний університет”, Національного медичного університету імені О. О. Богомольця - щодо запровадження форм документів, визначених наказом МОН України № 384 від 29 березня 2012 року "Про затвердження форм документів з підготовки кадрів у вищих медичних навчальних закладах I - IV рівнів акредитації' (у редакції наказу МОН України № 683 від 5 червня 2013 року). Необхідно зазначити, що наказом МОН України № 209 від 03.03.2014 року, зареєстрованим у
Міністерстві юстиції України 25.03.2014 року за № 368/25145, наказ МОН України № 384 від 29 березня 2012 року визнано таким, що втратив чинність; - ДВНЗ “Івано-Франківський національний медичний університет", Національного медичного університету імені О. О. Богомольця, ДЗ “Луганський державний медичний університет” - щодо організації роботи відділу ЄКТС та проведення моніторингу якості освіти відповідно до розробленого у навчальному закладі положення.

Необхідно наголосити, що основними завданнями таких відділів є розробка методології, методики моніторингу та забезпечення якості освіти; науковометодичне та організаційне забезпечення моніторингу якості знань студентів та інтернів; розробка єдиної системи критеріїв, діагностичного інструментарію, показників моніторингу якості знань; розробка комплексу показників, що забезпечують цілісне уявлення про стан освітнього процесу у вищому навчальному закладі, та систематизація інформації; прогнозування стану та розвитку освітнього процесу у вищому навчальному закладі та вироблення управлінських рішень; вивчення вітчизняного та світового досвіду у сфері вищої медичної (фармацевтичної) освіти та розробка рекомендацій; впровадження інноваційних розробок у навчально-методичну роботу та навчально-виховний процес. У ДВНЗ “Тернопільський державний медичний університет імені I. Я. Горбачевського MO3 України" створено інформаційно-аналітичний відділ, в складі якого $є$ групи: внутрішньоуніверситетського аналізу, загальноукраїнського аналізу, міжнародного аналізу.

Позитивним $\epsilon$ досвід запровадження анкетування студентів у системі заходів моніторингу якості надання освітніх послуг, наприклад у Запорізькому державному медичному університеті.

Системний підхід до організації навчально-виховного процесу на кафедрі, факультеті, у деканаті запроваджено у більшості вищих навчальних закладів. Найбільш регламентованим він $є$ у ВДНЗ України "Українська медична стоматологічна академія", Національному медичному університеті імені О. О. Богомольця, ДЗ “Дніпропетровська медична академія МОЗ України”.

Заслуговує на вивчення досвід Львівського національного медичного університету імені Данила Галицького щодо впровадження каталогу курсу “Інформаційний довідник ECTS" українською й англійською мовами, який містить вичерпну інформацію про університет, його структуру, систему ЄКТС, систему оцінювання, академічний календар, загальну і прак- 
тичну інформацію для студентів, структуру навчального плану зі спеціальності, опис програм дисциплін за весь період навчання і видається першокурсникам.

Необхідно додати, що каталог курсу внесений до ключових документів ECTS у Довіднику користувача Європейської кредитно-трансферної системи (Брюссель, 6 лютого 2009 року) [1, 4].

Позитивним є досвід Національного медичного університету імені О. О. Богомольця, ДУ 'Кримський державний медичний університет імені С. І. Георгієвського", Донецького національного медичного університету імені М. Горького щодо організації підготовки студентів до складання ліцензійних інтегрованих іспитів "Крок-1" та "Крок-2", зокрема щодо запровадження Методичних рекомендацій з підготовки до ліцензійних інтегрованих іспитів “Крок-1" i “Крок-2” як стандартизованої системи оцінювання якості освіти студента відповідно до вимог Болонського процесу у Національному медичному університеті імені О. О. Богомольця.

Досвід Донецького національного медичного університету імені М. Горького із впровадження розроблених фахівцями галузевої науково-методичної лабораторії з питань додипломної підготовки лікарів індивідуальних планів практичної підготовки студентів, що навчаються за спеціальностями "Лікувальна справа", "Педіатрія”, “Медико-профілактична справа", “Стоматологія", у тому числі для іноземних студентів, та використання в організації підготовки навчально-методичних матеріалів методичного посібника для викладачів вищих медичних навчальних закладів "Методологія і технологія визначення універсальних компетенцій випускників вищих медичних та стоматологічних факультетів", розробленого в університеті та впровадженого у діяльність ВМ(Ф)НЗ (лист МО3 України за підписом заступника Міністра № 08.01-47/907/18866 від 1 липня 2013 року).

Надзвичайно велику роль у покращенні оволодіння студентами та лікарями-інтернами практичних навичок відіграють університетські клініки (досвід Одеського національного медичного університету), навчально-виробничі об'єднання (Харківський національний медичний університет) та навчально-тренінгові центри (ДВНЗ “Івано-Франківський національний медичний університет”, ДВНЗ “Тернопільський державний медичний університет імені I. Я. Горбачевського"), сучасні високотехнологічні аудиторії (Національний медичний університет імені О. О. Богомольця, ДВНЗ “Тернопільський державний медичний університет імені І. Я. Горбачевського”, За- порізький державний медичний університет).

Ураховуючи те, що у ВМ(Ф)НЗ навчається значний відсоток іноземних студентів, доцільно використати досвід ДЗ “Луганський державний медичний університет”, Запорізького державного медичного університету, Харківського національного медичного університету щодо організації підготовки викладачів для роботи з іноземними студентами.

3 метою розповсюдження позитивного досвіду Одеського національного медичного університету, Д3 “Луганський державний медичний університет”, Запорізького державного медичного університету, Харківського національного медичного університету, ДВНЗ “Національний фармацевтичний університет” щодо організації роботи бібліотек вищих навчальних закладів, Міністерством охорони здоров'я України організовано та проведено 28 листопада 2013 року на базі Одеського національного медичного університету семінар для завідувачів бібліотек і відповідальних за впровадження бібліотечних систем $\mathrm{BM}(\Phi) \mathrm{H} 3$, за результатами якого підготовлені Методичні рекомендації з організації роботи інформаційно-технологічних систем бібліотеки вищого медичного (фармацевтичного) навчального закладу, затверджені MO3 України та надіслані для впровадження до усіх навчальних закладів з листом № 23-01-9/46 від 27 лютого 2014 року.

3 метою поширення досвіду Донецького національного медичного університету імені М. Горького щодо впровадження системи менеджменту якості згідно 3 вимогами національного стандарту ДСТУ ISO 9001:2009 та на виконання наказу MO3 України № 232-Адм від 28 жовтня 2013 року "Про проведення короткотривалих семінарів-тренінгів для начальників навчальних відділів та семінару для фахівців, відповідальних за впровадження системи менеджменту якості (згідно з вимогами ДСТУ ISO 9001 : 2009) у вищих медичних (фармацевтичному) навчальних закладах" 7 листопада 2013 року проведено на базі Донецького національного медичного університету імені М. Горького семінар, за результатами якого підготовлені Рекомендації з впровадження типової моделі системи менеджменту якості у вищих навчальних закладах MO3 України, затверджені в установленому порядку та надіслані з листом МO3 України № 08.01-47/2139/39725 від 16 грудня 2013 року в усі $\mathrm{BM}(\Phi) \mathrm{H} 3$.

У діяльність низки ВМ(Ф)НЗ впроваджено позитивний досвід ВДНЗ України “Буковинський державний медичний університет” і ДВНЗ “Тернопільський державний медичний університет імені I. Я. Горба- 
чевського МОЗ України" щодо використання у навчальному процесі інформаційно-комунікаційних освітніх технологій на базі програмного забезпечення з відкритим кодом.

Заслуговує на увагу розроблена у Вінницькому національному медичному університеті ім. М. І. Пирогова система комп'ютерної ідентифікації функцій людини “СКІФ” (моделювання процесів життєдіяльності організму людини), яка є підгрунтям розробки різних систем високотехнологічного навчання у теоретичній і практичній медицині, високоякісних тренажерних систем тощо. Медичні симулятори, побудовані на базі даної технології, можуть знайти застосування рівною мірою як у навчанні, так і у клінічній практиці.

У створенні кадрового потенціалу медичної галузі значну роль відіграють заклади післядипломної освіти. Для забезпечення безперервного професійного розвитку лікарів та провізорів у Національній академії післядипломної освіти імені П. Л. Шупика створені: портал “Сдиний медичний простір”, Всеукраїнська мережа дистанційної післядипломної освіти і телемедицини, система дистанційного контролю знань шляхом впровадження та забезпечення на практиці принципів адаптивності, дружнього інтерфейсу, самоконтролю знань суб'єктами навчання. Інноваційні технології широко застосовуються у навчальному процесі із слухачами Харківської та Запорізької академій післядипломної освіти, зокрема використовуються комплекси оперативного контролю знань (Smart Senteo), інтерактивні дошки (Smart Board), проводяться курси підвищення кваліфікації за темою "Розробка дистанційних курсів на платформі Moodle".

За ініціативи закладів післядипломної освіти проводяться науково-практичні та навчально-методичні школи і семінари для практикуючих лікарів та працівників академій: школи післядипломної освіти спільно 3 європейськими та міжнародними асоціаціями (НМАПО імені П. Шупика), школи молодого викладача (ХМАПО, ЗМАПО), семінар для завучів кафедр (ЗМАПО), школа молодого дисертанта, школа імунопрофілактики (ХМАПО).

Інноваційні педагогічні ідеїпідготовки тапідвищення кваліфікації фахівців медичного профілю впроваджує кафедра педагогіки, філософії та мовної підготовки ХМАПО, зокрема працівниками цієї кафедри видано навчально-методичний посібник "Моніторинг якості післядипломної медичної освіти на основі квалі- метричного підходу". Слід схвалити позитивний досвід щодо роботи ради опорних кафедр ХМАПО із координації навчальної, навчально-методичної та наукової діяльності профільних кафедр ВМ(Ф)НЗ України.

Моніторинговими групами МОЗ України відзначено як позитивний досвід роботи ЗМАПО щодо відкриття при академії науково-дослідних інститутів (НДІ трансплантології та серцево-судинної хірургії та НДІ очних хвороб), а також щодо розширення та удосконалення освітньої діяльності та охоплення нових цільових груп суб' єктів навчання, зокрема ліцензування нової освітньої послуги "Підвищення кваліфікації фахівців нелікарських спеціальностей у галузі знань "Медицина".

Висновок. Таким чином, проведення системного моніторингу навчально-методичної діяльності вищих навчальних закладів сприяє покращенню надання освітніх послуг. Разом з тим потребує постійного оновлення програма моніторингу. Водночас необхідно враховувати те, що перспективними напрямами забезпечення моніторингу та оцінювання якості освіти в Україні відповідно до Національної стратегії розвитку освіти в Україні на період до 2021 року (схвалена Указом Президента України № 344/2013 від 25 червня 2013 року) повинні стати:

- удосконалення системи зовнішнього незалежного оцінювання та моніторингу якості освіти, здійснення оплати праці працівників, залучених до проведення зовнішнього незалежного оцінювання;

- розроблення моделі проведення моніторингових досліджень для різних рівнів управління освітою;

- розроблення системи показників якості освіти на національному рівні, які відображають умови, процеси та освітні результати;

- проведення моніторингу якості ресурсного забезпечення, освітніх процесів і результатів;

- участь у міжнародних порівняльних дослідженнях якості освіти (TIMSS, PISA, PIRLS тощо);

- модернізація та оновлення системи освітньої статистики;

- забезпечення населення, органів управління, навчальних закладів достовірною інформацією стосовно умов і результативності функціонування системи освіти на різних їі рівнях;

- оприлюднення результатів проведення моніторингу системи освіти, зокрема засобами інформаційнокомунікаційних технологій. 


\section{Література}

1. Луговий В. І. Якість вищої освіти в Україні: проблеми забезпечення та визнання / В. І. Луговий, Ж. В. Таланова // Вища освіта України: Тематичний випуск “Свропейська інтеграція вищої освіти України в контексті Болонського процесу”. -2013. - № 3 (дод. 2). -256 с. -С. 6-10.

2. Методична робота як один із важливих розділів професійної діяльності науково-педагогічних працівників / О. П. Волосовець, Ю. С. П'ятницький, К. В. Баранніков [та ін.] // Матеріали Х ювілейної Всеукр. навч.- наук. конф. 3 міжнародною участю “Кредитно-модульна система організації навчального процесу у вищих медичних (фармацевтичному) навчальних закладах України на новому етапі". Т. : Укрмедкнига, 2013. - Ч. 1.-С. 89-91.

3. Аннєнкова І. П. Моніторинг якості освіти у ВНЗ / І. П. Аннєнкова. -О., 2010.-9 с.
4. Правові засади реалізації Болонського процесу в Україні : монографія / [В. Бугров, А. Гожик, К. Жданова та ін.] ; за заг. ред. В. Лугового, С. Калашнікової. - К. : ДП "НВЦ“"Пріоритети”, 2014. - 156 с.

5. Про затвердження Державних вимог до акредитації напряму підготовки спеціалістів та вищого навчального закладу: наказ Міністерства освіти і науки України № 689 від 13.06.2012 p.

6. Про затвердження норм часу для планування і обліку навчальної роботи та переліків основних видів методичної, наукової й організаційної роботи педагогічних і науково-педагогічних працівників вищих навчальних закладів : наказ Міністерства освіти і науки України № 450 від 07.08.2002p. 